\title{
Stable 8-hydroxyquinolinate based podates as efficient sensitizers of lanthanide near-infrared luminescence
}

\author{
Steve Comby, Daniel Imbert, Anne-Sophie Chauvin, Jean-Claude G. Bünzli \\ Laboratory of Lanthanide Supramolecular Chemistry, École Polytechnique Fédérale de \\ Lausanne (EPFL), BCH 1402, CH-1015 Lausanne, Switzerland
}

\section{Supporting Information (11 pages)}

RECEIVED DATE (to be automatically inserted after your manuscript is accepted if required according to the journal that you are submitting your paper to) 


\title{
1. Synthesis of the Ligands (Schemes 1 and 2).
}

\author{
$N, N, N^{\prime}, N^{\prime}$--tetracyanoethyl-1,2-ethylenediamine (1) ${ }^{1}$ and 7 -carboxy-8-hydroxyquinoline ${ }^{2}$
} were synthesized according to literature procedures.

$N, N, N$, $N$ '-tetraaminopropyl-1,2-ethylenediamine (2). $\mathrm{NaOH}$ (2.24 g, $56 \mathrm{mmol}$ ) was added to a solution of $\mathbf{1}$ (3 g, $11.02 \mathrm{mmol})$ in $95 \%$ ethanol $(60 \mathrm{~mL})$ at $0{ }^{\circ} \mathrm{C}$, followed by 14 $\mathrm{mL}$ of hydrazine $99 \%$ (288 mmol) and $1.94 \mathrm{~g}$ of Raney nickel (33.06 mmol) was introduced in small portions during $2 \mathrm{~h}$; the solution was stirred for $6 \mathrm{~h}$ at rt and then refluxed for $1 \mathrm{~h}$, hot-filtered and evaporated to give a colorless oil. Cycles of addition/evaporation of toluene were repeated until precipitation of $\mathrm{NaOH}$ occurred. Evaporation of the filtrate gave 2 as a colorless oil, which was used without further purification (2.48 g, 77\%). ${ }^{1} \mathrm{H}$ NMR (400 MHz, $\left.\mathrm{CDCl}_{3}\right): \delta=1.32\left(8 \mathrm{H}, \mathrm{s}, \mathrm{NH}_{2}\right), 1.58\left(8 \mathrm{H}, \mathrm{m}, \mathrm{CH}_{2}\right), 2.42-2.54\left(12 \mathrm{H}, \mathrm{m}, \mathrm{CH}_{2}\right), 2.72(8 \mathrm{H}, \mathrm{t}$, $\mathrm{CH}_{2}$ ). ESI-MS: $\mathrm{m} / \mathrm{z}=289.48[\mathrm{M}+\mathrm{H}]^{+}$(Calc. 289.37).

\section{$N$-\{2-\{Bis-[(8-hydroxyquinoline-7-carboxamido)propyl]-amino\}-ethyl $\}-N^{\prime}$-(8-} hydroxyquinoline-7-carboxamido)- $N$-[(8-hydroxyquinoline-7-carboxamido)propyl]propane-1,3-diamine (3, Tox). 7-carboxy-8-hydroxyquinoline (530 mg, $2.8 \mathrm{mmol}$ ) was dissolved in freshly distilled thf $(150 \mathrm{~mL})$ under nitrogen and heated to reflux. A solution of carbonyldiimidazole (CDI, $495 \mathrm{mg}, 3.05 \mathrm{mmol})$ in dry thf $(60 \mathrm{~mL})$ was added in $40 \mathrm{~min}$. Then a solution of $2(0.2 \mathrm{~g}, 0.70 \mathrm{mmol})$ in dry thf $(50 \mathrm{~mL})$ was added in $60 \mathrm{~min}$. The mixture was stirred overnight and evaporated. The resulting orange residue was dissolved in chloroform (300 mL), successively washed with saturated $\mathrm{NH}_{4} \mathrm{Cl}$ and brine, dried with $\mathrm{Na}_{2} \mathrm{SO}_{4}$ and evaporated to dryness. The residue was put three times through a Sephadex LH20 column (50\% MeOH-CH $\mathrm{Cl}_{2}$ ). An orange foam 3, eluted as a single band, was obtained (325 mg, 48\%). ${ }^{1} \mathrm{H}$ NMR (400 MHz, DMSO-d $\left.\mathrm{d}_{6}\right): \delta=1.83\left(8 \mathrm{H}, \mathrm{m}, \mathrm{CH}_{2}\right), 2.28\left(8 \mathrm{H}, \mathrm{m}, \mathrm{CH}_{2}\right)$, $3.12\left(4 \mathrm{H}, \mathrm{s}, \mathrm{CH}_{2}\right), 3.48\left(8 \mathrm{H}, \mathrm{s}, \mathrm{CH}_{2}\right), 7.28$ (4H, d, $\left.\mathrm{ArH}\right), 7.59$ (4H, dd, $\left.\mathrm{ArH}\right), 7.92(4 \mathrm{H}, \mathrm{d}$, ArH), 8.26 (4H, d, ArH), 8.87 (4H, d, ArH), 8.97 (4H, s, NH). IR (ATR): $\tilde{v}=3460-3200$,

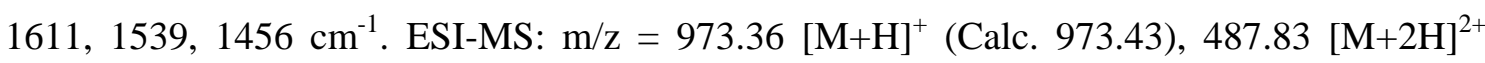
(Calc. 487.54), $325.83[\mathrm{M}+3 \mathrm{H}]^{3+}$ (Calc. 325.54). Anal. Calcd. for $\mathrm{C}_{54} \mathrm{H}_{56} \mathrm{~N}_{10} \mathrm{O}_{8} \cdot \mathrm{CH}_{2} \mathrm{Cl}_{2}$ : C, 62.2; H, 5.7; N, 12.9. Found: C, 62.4; H, 5.5; N, 13.2.

\section{$N$-\{2-\{Bis-[(5-sulfo-8-hydroxyquinoline-7-carboxamido)propyl]-amino\}-ethyl\}- $N^{\prime}-(5-$} sulfo-8-hydroxyquinoline-7-carboxamidomethyl)- $N$-[(5-sulfo-8-hydroxyquinoline-7carboxamidomethyl)propyl]-propane-1,3-diamine (4, Tsox). $180 \mathrm{mg}$ of 3 (0.185 mmol) was placed in a round bottom flask and covered by a minimum of oleum $\left(\mathrm{H}_{2} \mathrm{SO}_{4}, \mathrm{SO}_{3} 30 \%\right)$. The mixture was stirred at rt overnight and poured on ice, yielding a precipitate which was 
filtrated and washed with cold water. The collected solid $\mathbf{4}$ was dried under vacuum during 72 h to give a brown powder (198 mg, 83\%). ${ }^{1} \mathrm{H}-\mathrm{NMR}$ (400 MHz in DMSO-d 6 ): $\delta=1.99(8 \mathrm{H}$, m, $\mathrm{CH}_{2}$ ), 3.26 (8H, m, $\mathrm{CH}_{2}$ ), 3.46 (8H, m, $\mathrm{CH}_{2}$ ), 3.52 (4H, m, $\left.\mathrm{CH}_{2}\right), 7.85$ (4H, dd, $\left.\mathrm{ArH}\right), 8.44$ (4H, s, ArH), 8.96 (4H, d, ArH), 9.31 (4H, t, NH), 9.45 (4H, d, ArH). IR (ATR): 3500-3100 $\mathrm{cm}^{-1} \tilde{v}(\mathrm{O}-\mathrm{H}), \tilde{v}(\mathrm{~N}-\mathrm{H}) ; 1637 \mathrm{~cm}^{-1} \tilde{v}(\mathrm{C}=\mathrm{O}), 1599,1539 \mathrm{~cm}^{-1} \tilde{v}(\mathrm{C}=\mathrm{C}), \tilde{v}(\mathrm{C}=\mathrm{N})$. ESI-TOF MS: 322.17 [L-4H] $]^{4-}$ (Calcd. 321.55). Anal. Calcd. for $\mathrm{C}_{54} \mathrm{H}_{58} \mathrm{~N}_{10} \mathrm{O}_{20} \mathrm{~S}_{4} \cdot 8 \mathrm{H}_{2} \mathrm{O}$ : C, 45.1; H, 5.2; N, 9.7. Found: C, 45.1; H, 4.8; N, 9.5.

$N, N, N^{\prime}, N^{\prime}$-tetramethylaminopropyl-1,2-ethylenediamine (5). A solution of 2 (1 g, 3.47 mmol) dissolved in a mixture of toluene $(4 \mathrm{~mL})$ and water $(2 \mathrm{~mL})$ was cooled at $5{ }^{\circ} \mathrm{C}$, ethylchloroformate (1 g, $9.20 \mathrm{mmol}$ ) was added in $15 \mathrm{~min}$, and $\mathrm{KOH}$ (843 mg, $15 \mathrm{mmol}$ ) in water $(0.8 \mathrm{~mL})$ was added in $15 \mathrm{~min}$ with more ethylchloroformate $(1 \mathrm{~g}, 9.20 \mathrm{mmol})$. The mixture was stirred $2 \mathrm{~h}$ at $5{ }^{\circ} \mathrm{C}$ and then $8 \mathrm{~h}$ at rt. The toluene layer was separated and the aqueous one extracted with chloroform (300 mL), dried with $\mathrm{MgSO}_{4}$ and evaporated to dryness. The resulting oil (1.98 g, 99 \%) was used without further purifications in the next step. It was dissolved in freshly distilled thf $(30 \mathrm{~mL})$ and added in $30 \mathrm{~min}$ to a solution of $\mathrm{LiAlH}_{4}(810 \mathrm{mg}, 21.3 \mathrm{mmol})$ in freshly distilled thf $(30 \mathrm{~mL})$, heated to reflux and then the mixture was stirred overnight. $\mathrm{KOH}(1.4 \mathrm{~g}$ in $1.4 \mathrm{~mL}$ water) was added dropwise and the solution was decanted and filtrated. After evaporation to dryness, the resulting oil was distilled, yielding a colorless oil (400 mg, 33\%). ${ }^{1} \mathrm{H}$ NMR (400 MHz, $\left.\mathrm{CDCl}_{3}\right): \delta=1.39(4 \mathrm{H}$, s, NH), $1.51\left(12 \mathrm{H}, \mathrm{m}, \mathrm{CH}_{2}\right), 2.36-2.43\left(20 \mathrm{H}, \mathrm{m}, \mathrm{CH}_{2}\right), 2.65\left(8 \mathrm{H}, \mathrm{t}, \mathrm{CH}_{2}\right) . \mathrm{ESI}-\mathrm{MS}: \mathrm{m} / \mathrm{z}=$ $345.33[\mathrm{M}+\mathrm{H}]^{+}$(Calc. 344.34).

\section{$N$-\{2-\{Bis-[(8-hydroxyquinoline-7-carboxamidomethyl)propyl]-amino\}-ethyl\}- $N^{\prime}-(8-$}

hydroxyquinoline-7-carboxamidomethyl)- $N$-[(8-hydroxyquinoline-7-

carboxamidomethyl)propyl]-propane-1,3-diamine (6, ToxMe). This compound was prepared according to the same synthetic procedure described for the synthesis of $\mathbf{3}$ by using 7-carboxy-8-hydroxyquinoline (880 $\mathrm{mg}, 4.64 \mathrm{mmol})$ in thf $(60 \mathrm{~mL})$, carbonyldiimidazole (CDI, $830 \mathrm{mg}, 5.11 \mathrm{mmol})$ in thf (60 mL), and 5 (400 mg, $1.16 \mathrm{mmol})$ in thf (120 mL); 6 was eluted as a single band and obtained as an orange foam (185 mg, $16 \%$ ). ${ }^{1} \mathrm{H}$ NMR (400 MHz, $\left.\mathrm{CDCl}_{3}\right): \delta=1.82\left(8 \mathrm{H}, \mathrm{m}, \mathrm{CH}_{2}\right), 2.48\left(8 \mathrm{H}, \mathrm{m}, \mathrm{CH}_{2}\right), 2.84\left(4 \mathrm{H}, \mathrm{m}, \mathrm{CH}_{2}\right), 3.02\left(12 \mathrm{H}, \mathrm{s}, \mathrm{CH}_{2}\right)$, $3.46\left(8 \mathrm{H}, \mathrm{s}, \mathrm{CH}_{2}\right), 7.35$ (4H, d, ArH), 7.47 (8H, m, ArH), $8.16(4 \mathrm{H}, \mathrm{d}, \mathrm{ArH}), 8.84(4 \mathrm{H}, \mathrm{d}$,

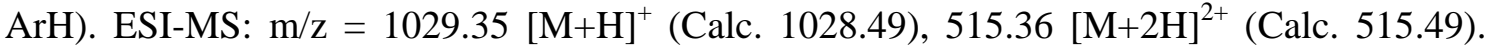
Anal. Calcd. for $\mathrm{C}_{54} \mathrm{H}_{56} \mathrm{~N}_{10} \mathrm{O}_{8} \cdot \mathrm{CH}_{2} \mathrm{Cl}_{2}$ : C, 62.2; H, 5.7; N, 12.9. Found: C, 62.4; H, 5.5; N, 13.2 . 


\section{$N$-\{2-\{Bis-[(5-sulfo-8-hydroxyquinoline-7-carboxamidomethyl)propyl]-amino\}-ethyl\}-} $N$ '-(5-sulfo-8-hydroxyquinoline-7-carboxamidomethyl)- $N$-[(5-sulfo-8-hydroxyquinoline7-carboxamidomethyl)propyl]-propane-1,3-diamine (7, TsoxMe). $185 \mathrm{mg}$ of 6 (0.180 mmol) was placed in a round bottom flask and covered by a minimum of oleum $\left(\mathrm{H}_{2} \mathrm{SO}_{4}, \mathrm{SO}_{3}\right.$ $30 \%)$. The mixture was stirred at rt overnight, poured on ice, and evaporated. The residue was put five times through a Sephadex G-25 column (water). The collected solid 7 was dried under vacuum during $72 \mathrm{~h}$ to give a brown foam (137 mg, 57\%). ${ }^{1} \mathrm{H}-\mathrm{NMR}$ (400 $\mathrm{MHz}$ in DMSO-d $\left.\mathrm{d}_{6}\right): \delta=1.94\left(8 \mathrm{H}, \mathrm{m}, \mathrm{CH}_{2}\right), 2.87\left(8 \mathrm{H}, \mathrm{m}, \mathrm{CH}_{2}\right), 3.01\left(12 \mathrm{H}, \mathrm{m}, \mathrm{CH}_{3}\right), 3.43(4 \mathrm{H}, \mathrm{s}$, $\mathrm{CH}_{2}$ ), $3.60\left(8 \mathrm{H}, \mathrm{m}, \mathrm{CH}_{2}\right)$. Anal. Calcd. for $\mathrm{C}_{58} \mathrm{H}_{66} \mathrm{~N}_{10} \mathrm{O}_{20} \mathrm{~S}_{4} \cdot 5 \mathrm{H}_{2} \mathrm{SO}_{4} \cdot 14 \mathrm{H}_{2} \mathrm{O}$ : C, 33.3; H, 5.0; N, 6.7. Found: C, 33.3; H, 4.9; N, 6.8.

\section{References}

1) van Duijvenbode, R. C.; Rajanayagam, A.; Koper, G. J. M.; Borkovec, M.; Paulus, W.; Steuerle, U.; Haussling, L. Phys. Chem. Chem. Phys. 1999, 1, 5649-5652.

2) Baret, P.; Beguin, C. G.; Boukhalfa, H.; Caris, C.; Laulhere, J. P.; Pierre, J. L.; Serratrice, G. J. Am. Chem. Soc. 1995, 117, 9760-9761. 


\section{Supplementary figures}

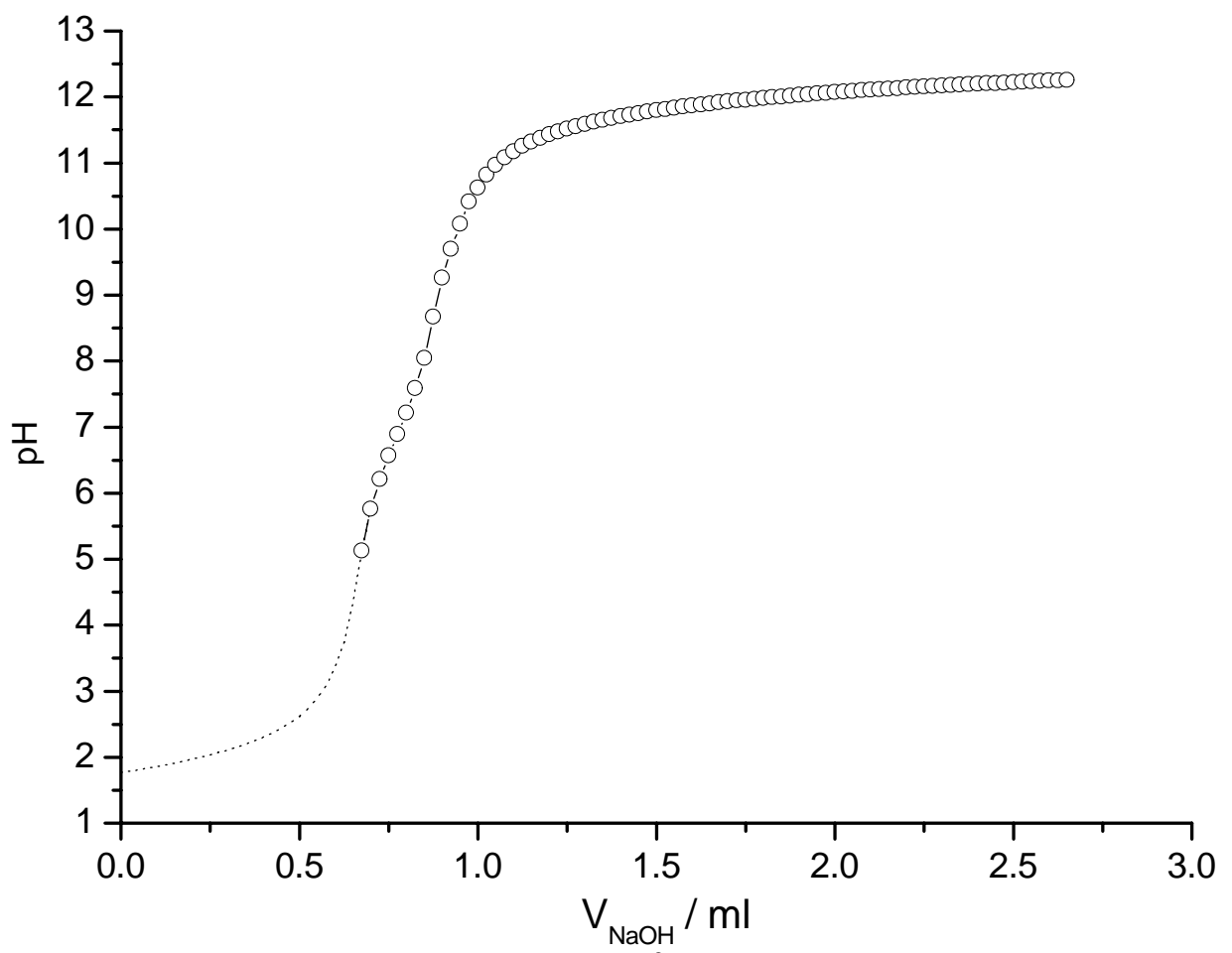

Figure S1. Potentiometric titration curve of $\mathrm{H}_{10} \mathrm{~L}^{2+}$ with $\mathrm{OH}^{-}$in water: [Tsox] $=9.41 \cdot 10^{-4} \mathrm{M}$; $T=25.0 \pm 0.1^{\circ} \mathrm{C} ; \mu=0.1 \mathrm{M}(\mathrm{KCl}) .(\cdots)$ precipitation below $\mathrm{pH}=5.5$.

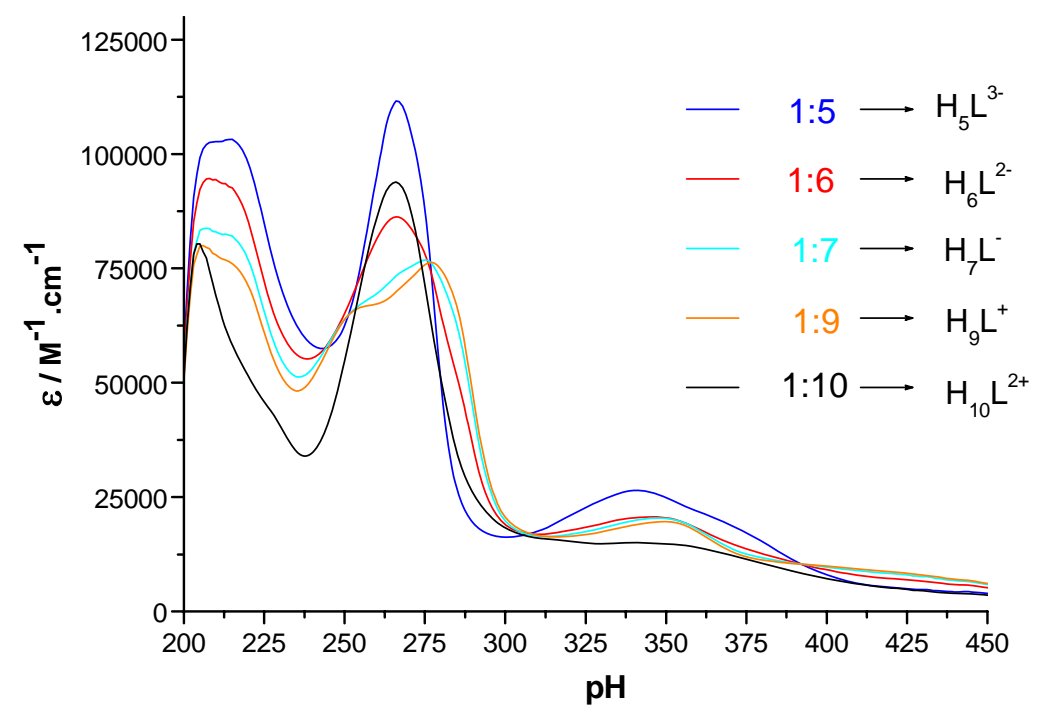

Figure S2. Calculated UV-Vis absorption spectra of the various protonated species of Tsox. 

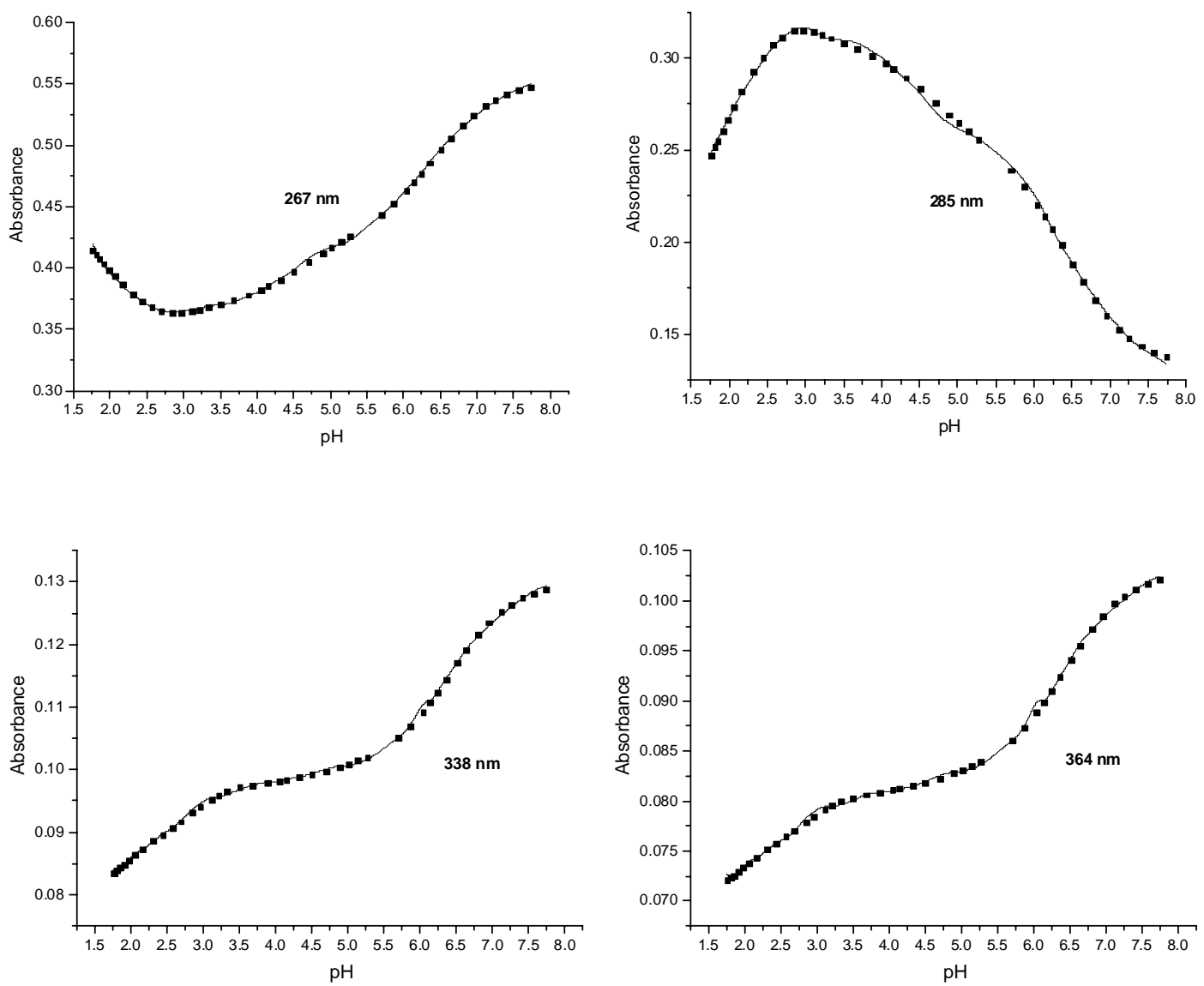

Figure S3. Absorbance variation of Tsox at different wavelengths in function of $\mathrm{pH}$.

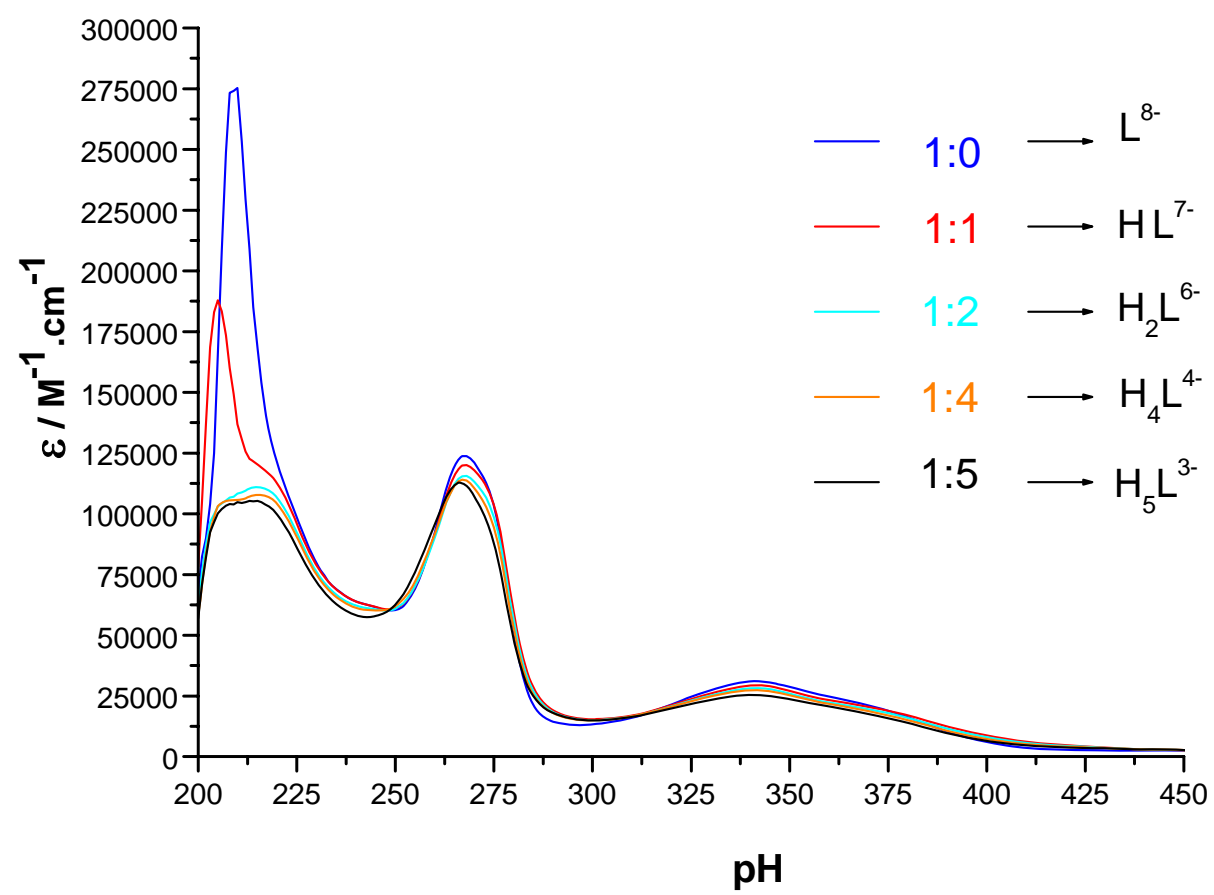


Figure S4. Calculated UV-Vis absorption spectra of the various protonated species of Tsox.
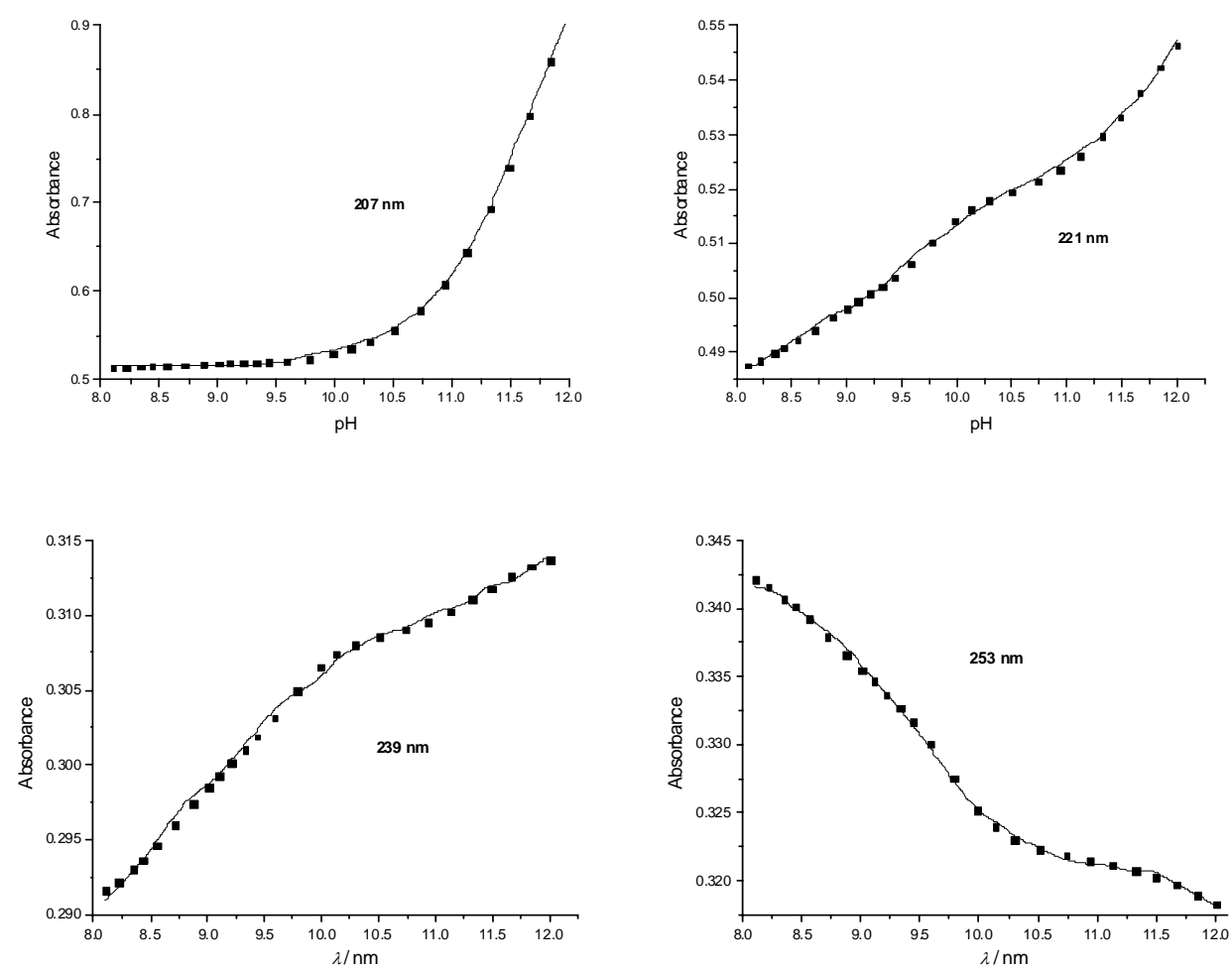

Figure S5. Absorbance variation of Tsox at different wavelengths in function of $\mathrm{pH}$. 


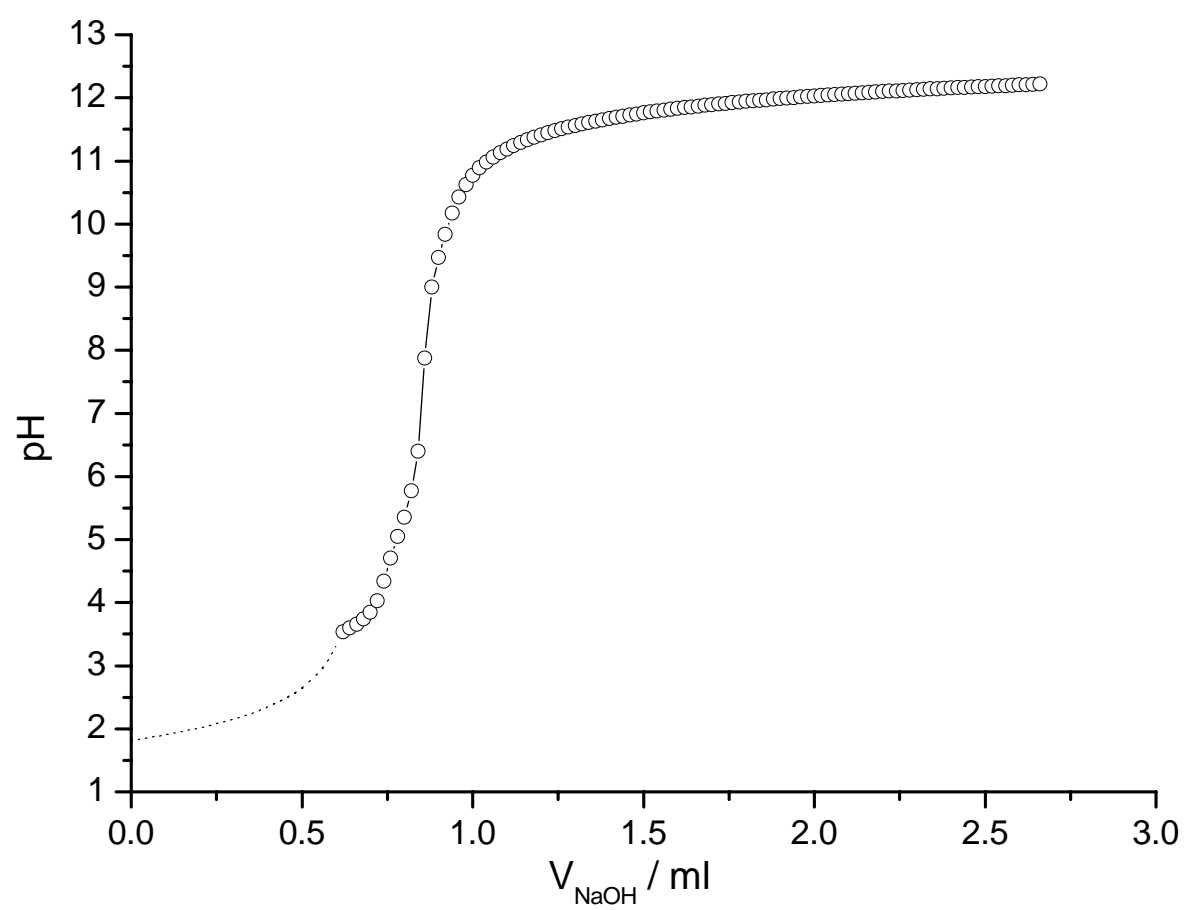

Figure S6: Potentiometric titration curve with $\mathrm{OH}^{-}$of $\mathrm{H}_{10} \mathrm{~L}^{2+}$ and 1 equivalent of $\mathrm{Eu}^{\mathrm{III}}$ in water: $[$ Tsox $]=9.41 \cdot 10^{-4} \mathrm{M} ; T=25.0 \pm 0.1^{\circ} \mathrm{C} ; \mu=0.1 \mathrm{M}(\mathrm{KCl}) .(\ldots)$ precipitation below $\mathrm{pH}$ 3.5 . 


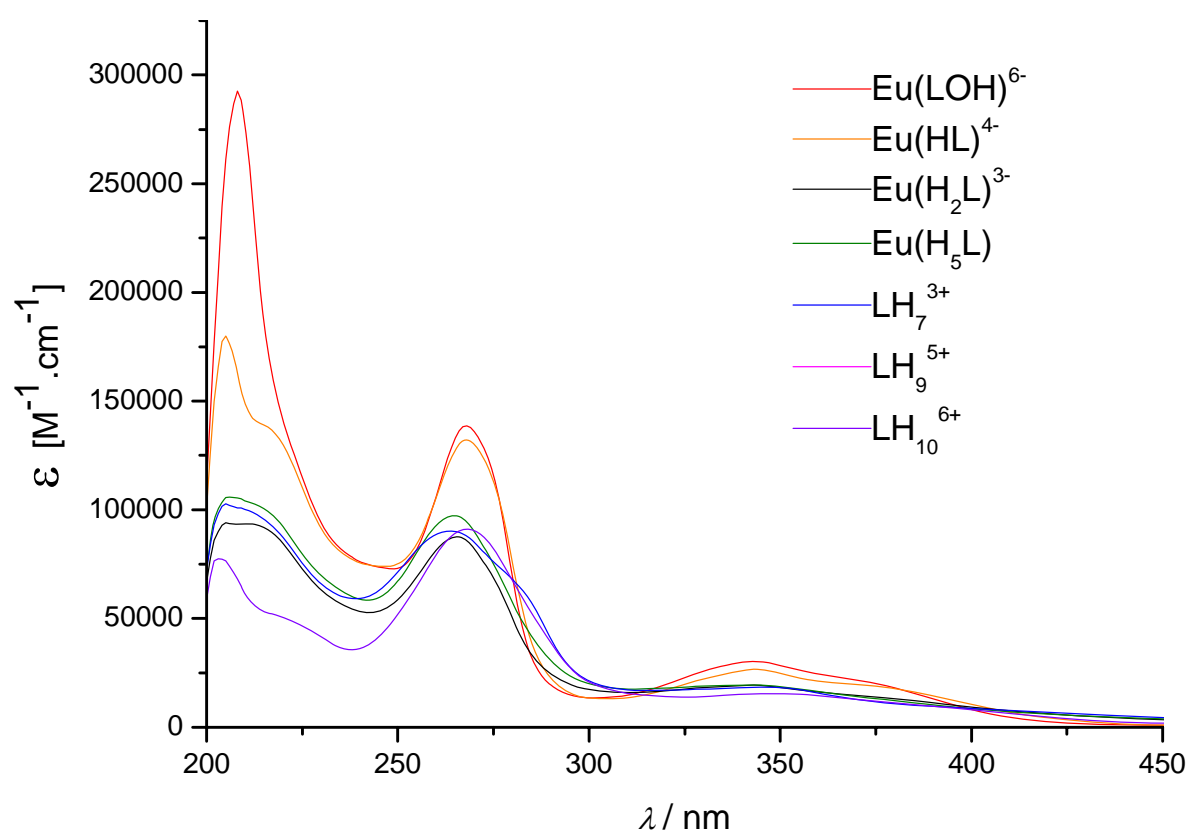

Figure S7. Calculated UV-Vis absorption spectra of the various protonated species of Tsox in presence of one equivalent of $\mathrm{Eu}^{\mathrm{III}}$.
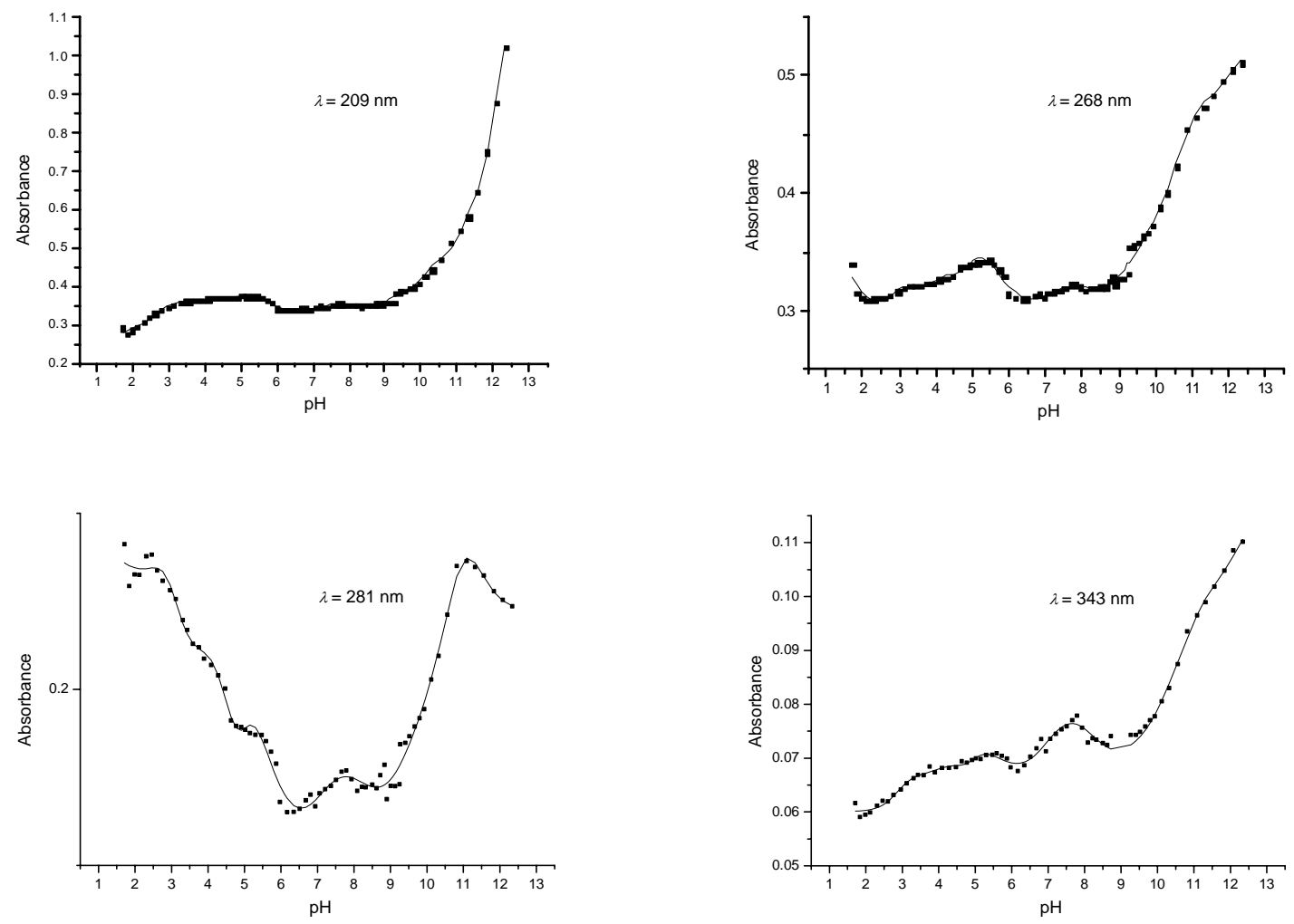
Figure S8. Absorbance variation of Tsox in presence of one equivalent of $\mathrm{Eu}^{\mathrm{III}}$ at different wavelengths in function of $\mathrm{pH}$
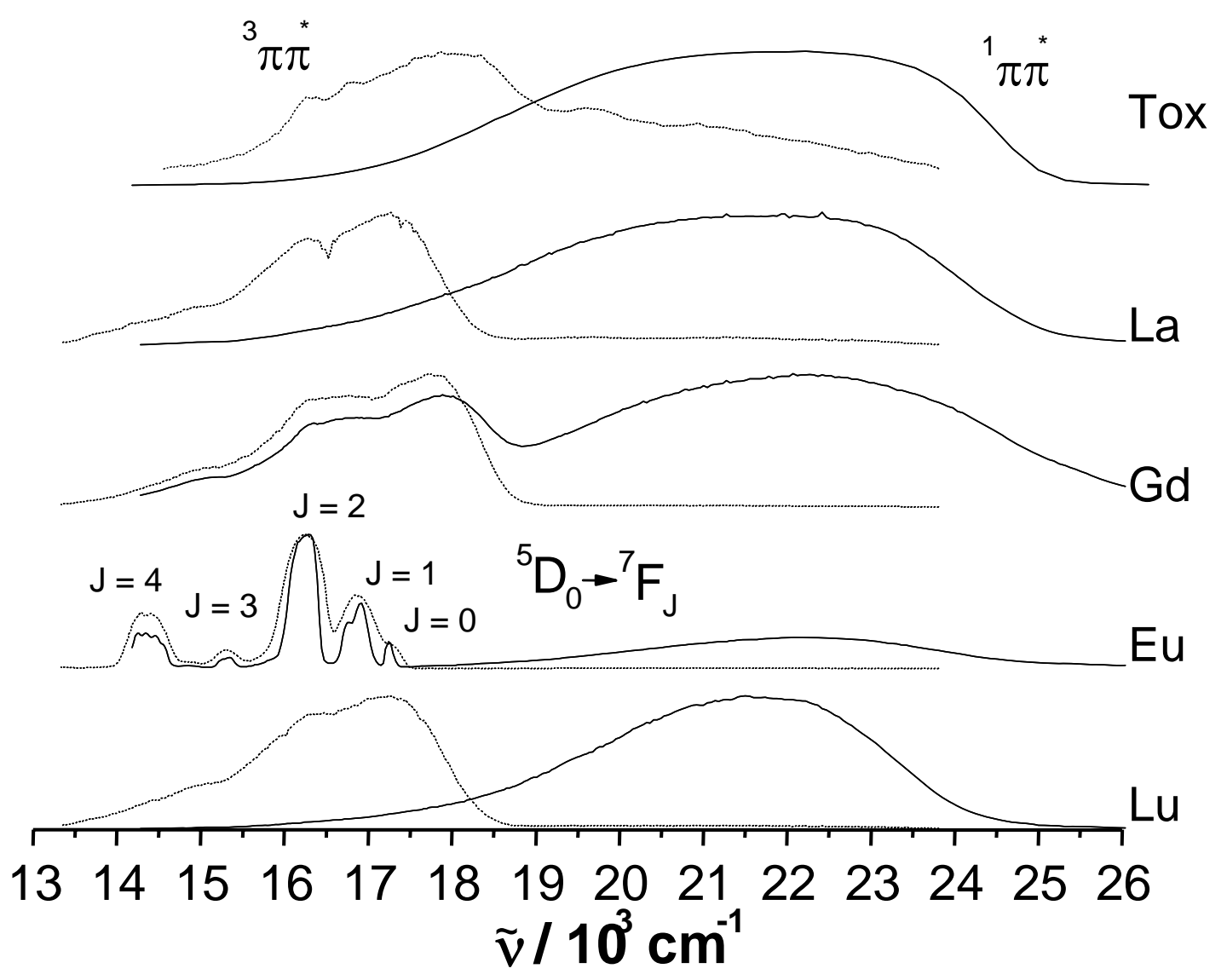

Figure S9. Luminescence spectra of Tox and its $1: 1$ complexes $6 \cdot 10^{-5} \mathrm{M}$ in methanol at $77 \mathrm{~K}$ without time delay (solid line) and with a 0.05 ms time delay (dotted line). 


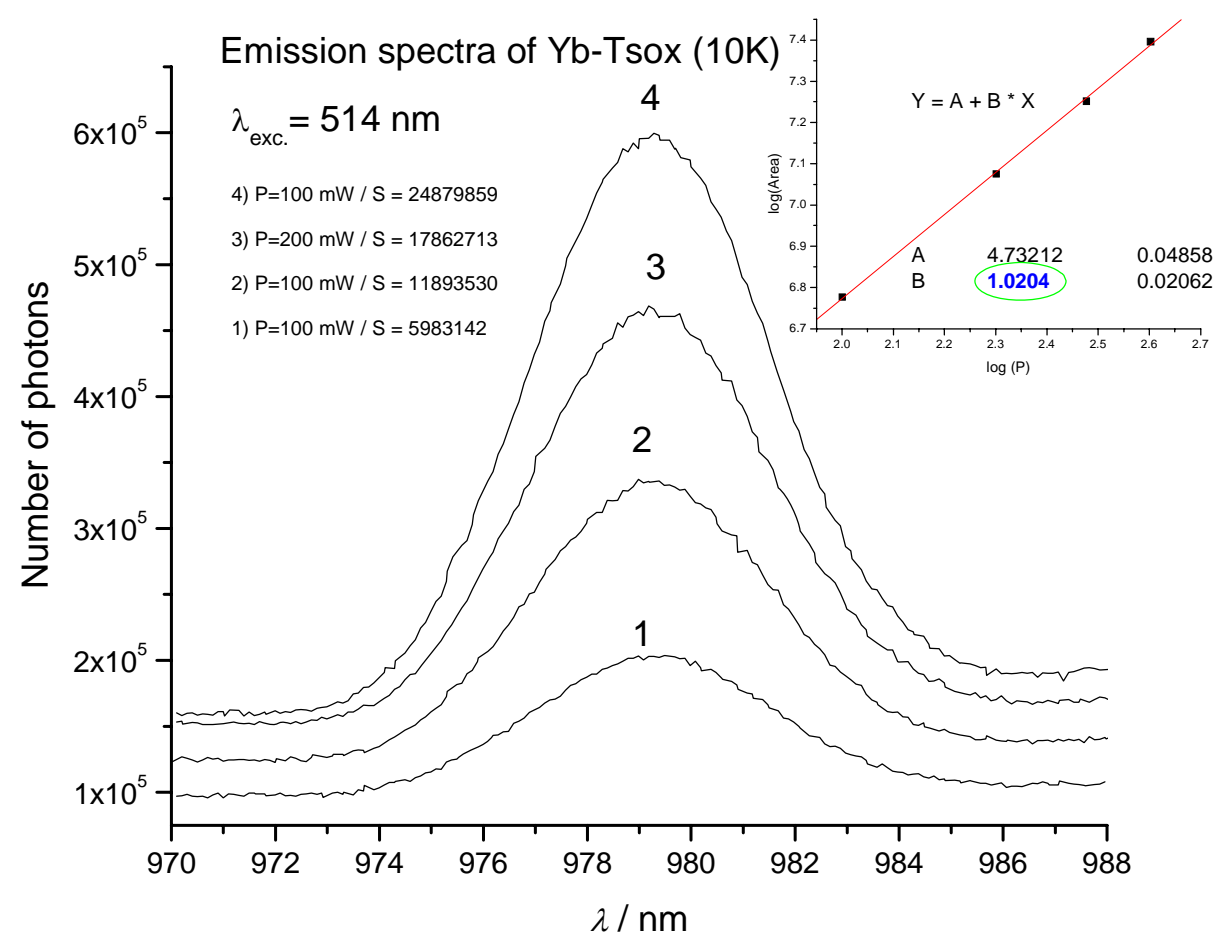

Figure S10. Luminescence intensity of the $\mathrm{Yb}-\mathrm{Tsox}\left(\lambda_{\mathrm{an}}=979 \mathrm{~nm}\right)$ complex versus the power of the laser (514 nm) at pH 7.4 in HBS buffer at $10 \mathrm{~K}$.
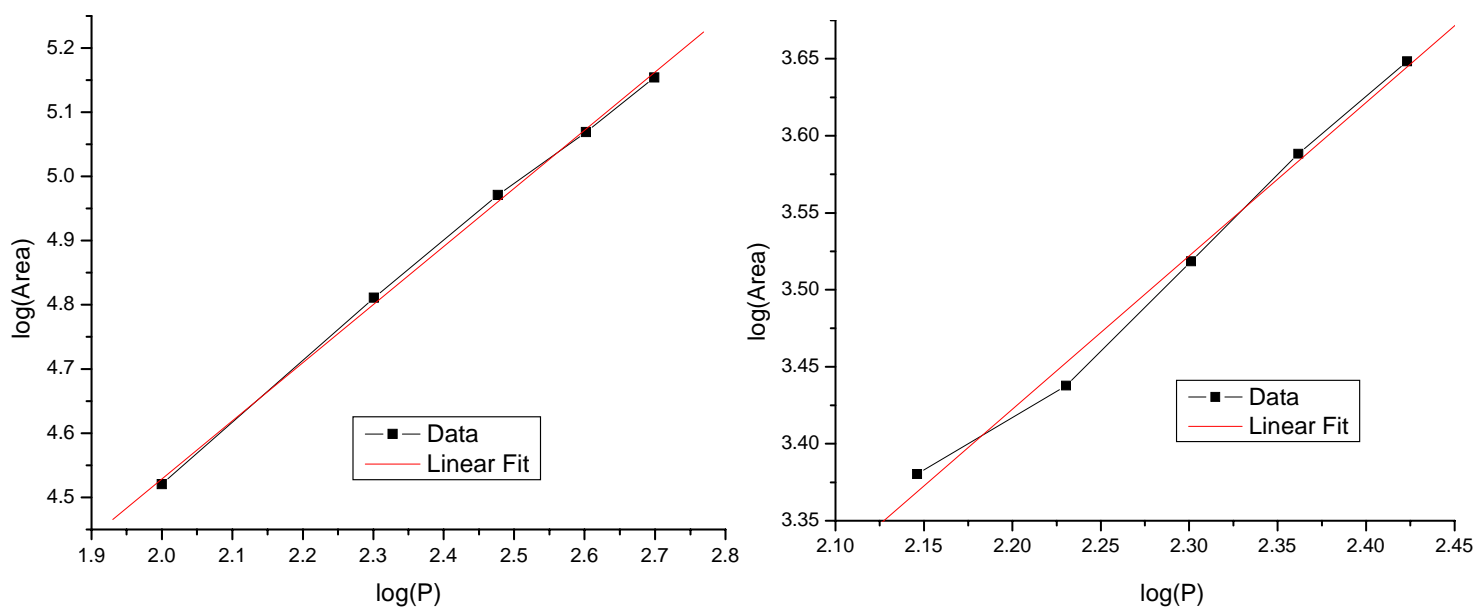

Figure S11. Luminescence intensity of the $\mathrm{Yb}-\mathrm{Tsox}\left(\lambda_{\mathrm{an}}=979 \mathrm{~nm}\right)$ complex versus the power of the laser (Left: $580 \mathrm{~nm}$, Right: $355 \mathrm{~nm}$ ) at pH 7.4 in HBS buffer at $10 \mathrm{~K}$ 

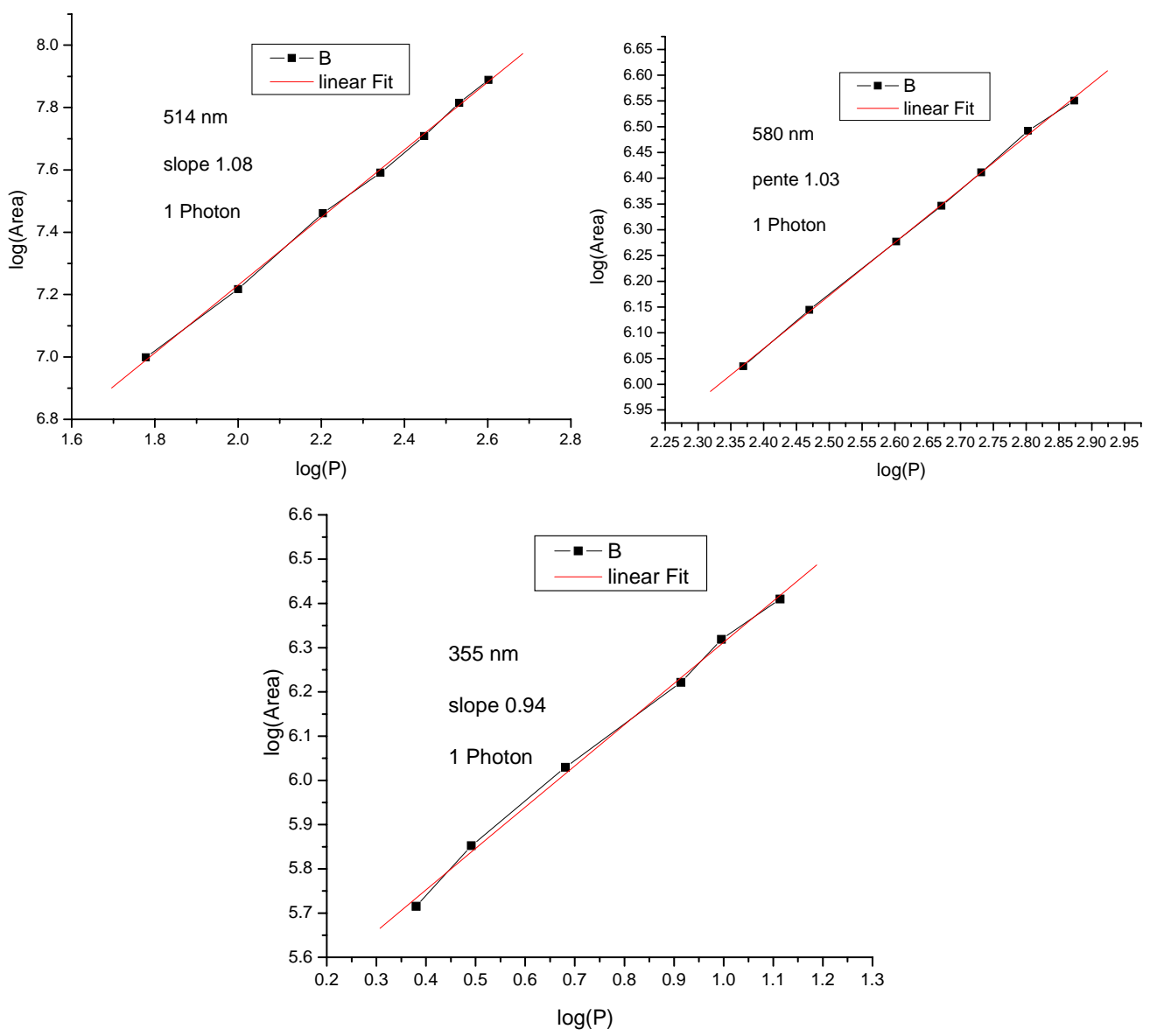

Figure S12. Luminescence intensity of the Yb-TsoxMe $\left(\lambda_{\text {an }}=979 \mathrm{~nm}\right)$ complex versus the power of the laser $(355,514$ and $580 \mathrm{~nm})$ at pH 7.4 in HBS buffer at $10 \mathrm{~K}$. 